\title{
Family and School Condition Toward Student English Achievement
}

\author{
Verdana Islami Alwi Syahrilla putri ${ }^{1 *}$, Syahrul ${ }^{2 *}$, M. Melani ${ }^{3 *}$ (D)

\section{A R T I C L E I N F O}

Article history:

Received April 25, 2021

Revised April 27, 2021

Accepted June 18, 2021

Available online August 25, 2021

Kata Kunci:

Prestasi Belajar, Kondisi keluarga,

Kondisi Sekolah

Keywords:

Learning Achievement, Family

Condition, School Condition.

DOI:

http://dx.doi.org/10.23887/jpbi.v9i2. $\underline{35603}$

\begin{abstract}
A B S T R A K
Lingkungan sekolah terkadang juga menjadi faktor penghambat bagi siswa, misalnya cara penyajian pelajaran yang kurang baik. Selain itu, masih banyak orang tua yang kurang memperhatikan pendidikan siswanya. Hal ini berdampak pada keterampilan Bahasa Inggris siswa yang rendah. Penelitian ini bertujuan untuk menganalisis kondisi keluarga dan sekolah terhadap prestasi bahasa inggris siswa. Penelitian ini merupakan penelitian korelasional. Subjek penelitian adalah sетиa siswa kelas berjumlah 24 siswa. Metode yang digunakan untuk mengumpulkan data adalah observasi, wawancara, dan angket. Instrumen yang digunakan dalam pengumpulan data adalah angket. Teknik yang digunakan untuk menganalisis data adalah statistik deskriptif kualitatif, dan kuantitatif. Hasil penelitian yaitu kondisi keluarga berpengaruh positif terhadap prestasi belajar bidang studi bahasa inggris. hal ini menunjukkan bahwa Apabila kondisi keluarga meningkat, maka prestasi belajar siswa juga akan meningkat. Uji parsial (Uji t) diperoleh $t$ hitung variabel pengaruh kondisi keluarga $=6.607$ sehingga $\mathrm{Ha} \mathrm{X1}$ terhadap Y diterima. Variabel pengaruh kondisi sekolah diperoleh thitung $=3.019$, sehingga Ha X2 terhadap Y diterima. Sumbangan efektif kondisi keluarga sebesar 21.316\%, kondisi sekolah sebesar 39.678\%. Dapat disimpulkan bahwa terdapat pengaruh secara simultan kondisi keluarga dan sekolah terhadap pembelajaran mata pelajaran Bahasa Inggris.
\end{abstract}

\section{A B S T RA C T}

The school environment is also an inhibiting factor for students. For example, the way the lesson is presented is not good. In addition, there are still many parents who ignore the education of their students. This has an impact on students' low English skills. This study aims to analyze family and school conditions on students' English achievement. This research is a correlational study. The research subjects were all students of the class with 24 students. The method used to collect data is observation, interviews, and questionnaires. The instrument used in data collection is a questionnaire. The technique used to analyze the data is descriptive qualitative statistics, and quantitative. The study results are that family conditions have a positive effect on learning achievement in learning English. This shows that when family conditions improve, student achievement will also increase. Partial test (t-test) obtained t count variable influence of family conditions $=6.607$ so that $\mathrm{Ha} \mathrm{X1}$ against $\mathrm{Y}$ is accepted. Variable influence of school conditions t count $=3.019$ so that $\mathrm{Ha} \mathrm{X} 2$ to $\mathrm{Y}$ is accepted. The practical contribution of family conditions is $21.316 \%$, school conditions are $39.678 \%$. The key is that there is a simultaneous influence of family and school conditions on learning English subjects.

This is an open-access article under the CC BY-SA license. Copyright @ 2021 by Author. Published by Universitas Pendidikan Ganesha.

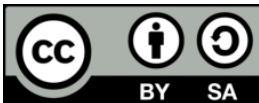

\section{INTRODUCTION}

Education is the most crucial element and must be adequately considered by every citizen. Through education, people will develop their abilities and skills (Purwanita et al., 2019; Wau, 2017). Education will lead a person in a better direction (Chauhan, 2017; Nurlaily et al., 2019; Tempelaar Chan et al., 2021). One of the activities obtained during participating in educational activities is learning. Learning is a combination element composed of facilities, equipment, and procedures that influence each other to achieve maximum learning goals (Akhmalia et al., 2018; Retnawati, 2016). In the learning process, there will be an interaction between students and teachers and the environment. Thus, the learning process occurs not only between teachers and students but also with other sources (Balan et al., 2019; Rubini et al., 2018). One of the subjects that students get is a foreign language. A language is a tool for expressing meaning through language words and vocabulary (Sert \& Boynueğri, 2017; Trentman, 2017). Thus language plays an essential role in human life. Language is increasingly functioning in one's language use, and it can be seen from the quality and capacity of the vocabulary it has (Moghadam et al., 2021; Potvin et al., 2021). The foreign language obtained by students during their education is English.

English is a communication tool orally and in writing. In English lessons, all students must learn four basic skills, namely listening, speaking, reading, and writing (Butova et al., 2019; Sert \& Boynueğri, 2017). 
Listening is a listening skill to be used in English. The primary purpose of speaking ability is to convey messages to others, namely being able to communicate in a language (Butova et al., 2019; Yusuf \& Mabagits, 2020). Writing skill is considered the most challenging skill compared to other language skills. Writing skills are needed by students. Reading is an activity that is very complicated or complex because it depends on the language skills of the learner and the level of the offer. The purpose of someone reading is to understand or understand the content of the message contained in reading as efficiently as possible (Chotitham \& Wongwanich, 2014; Creed et al., 2012; Moghadam et al., 2021). English language skills must be mastered by students so that students can compete internationally. The ability to speak English can also be used by students who later in the world of work.

One of the institutions that influence students to influence achievement is the school. The school environment is sometimes also an inhibiting factor for students. For example, the way the lesson is presented is not good, the teacher-student relationship is not good, the relationship between students is not happy, and the learning tools in the school are not complete will affect students' skills (Arianti et al., 2019; Diana Putra et al., 2019; Prabaningrum \& Putra, 2019). Based on preliminary research by interviewing one of the English teachers at SMPN 2 Sungaipua on March 14, 2019, it was found that learning achievement in English was still inadequate and often decreased. The decline in learning achievement can be seen from the daily test scores and mid-semester scores which are still relatively low for minimum completeness requirements. This shows that student achievement is not by the minimum completeness criteria (KKM).

Based on the results of interviews conducted with teachers, it was found that there were still many parents who ignored the education of their students. Many parents object when students are required to buy learning books to support the materials they need. Therefore, students are not optimally involved in the learning process. Parents do not mind if there is an invitation from the school to attend a meeting or distribute report cards. Some of them did not come or asked others to come on their behalf. As a result, these parents do not know their children's development and learning abilities at school. Based on the interviews with several students, it was found that the learning facilities in schools were not complete. There were still many who did not have the textbooks and dictionaries needed in English learning activities. There are not enough books in the library. The laboratory at the school also does not have internet facilities. The lack of these facilities will hinder student learning progress because learning facilities supporting teaching and learning outcomes become inefficient. Some students who like the teacher who teaches them also like the lesson, and some do not like the teacher. They do not like the lesson either.

Teachers must be responsible for the results of children's learning activities through learning. This is because the teacher is a factor that influences the success or failure of the learning process (Nurlaily et al., 2019; Tsai et al., 2020). Teachers must master the principles of learning and master the material to be taught (Verner et al., 2013; Wongwanich et al., 2014).In other words, the teacher must create the best possible learning conditions so that students can learn quickly (Erichsen \& Reynolds, 2020; Soisangwarn \& Wongwanich, 2014). Teachers hold various types of roles that must be carried out as a teacher. The role of teachers in improving the quality of education is one of the steps that can be taken to improve and advance human resources (Agustuna et al., 2019; Mudiyantun, 2019). In schools, teachers are present to devote themselves to humanity, in this case, students. Teachers are responsible for implementing the learning system to work well (Ambussaidi \& Yang, 2019; Schildkamp et al., 2020). Teachers are not only required to be able to stimulate their students to learn but also must be able to pay attention to the diversity that exists because the absorption capacity of students can vary, and the accumulation of previous learning experiences varies from one to another (Slade et al., 2019; Timmermans et al., 2019). Teachers also have a responsibility to see everything that happens in the classroom to help develop the child. In addition to teachers, parents also have an essential role in improving students' skills.

Parents are their children's primary and first educators because they receive their first education (Creed et al., 2012; Dong et al., 2020). Thus the first form of education is in the family. Parents or mothers and fathers play an important and very influential role in the education of their children. A mother's education for her child is a primary education that cannot be ignored at all (Cheung \& Yin, 2021; Kuppens \& Ceulemans, 2019)The responsibilities of parents to children include various things, including shaping a child's personality, not only in the physical order (material), also in mental (spiritual), moral, religious life in daily life (Cheung, SCheung \& Kwan, 2021; Dong et al., 2020). This causes parents to be obliged to hone their children's skills from an early age so that their children's English skills or abilities become good.

The findings of previous research stated that teachers have an essential task to improve students' English skills (Agustuna et al., 2019; Alam \& Lestari, 2020; Potvin et al., 2021). Other research findings also state that parents also have an important role in the formation of children's skills (Rosalina et al., 2010; Yulianingsih et al., 2020). There is no study on family and school conditions on students' English achievement. Based on the problems found by researchers in the preliminary study, this study aims to analyze the condition of family and school on students' English achievement. It is expected that families and schools can improve students' English language skills to have good English language skills. 


\section{METHOD}

This research is correlation research. It is a research study that involves collecting data to determine whether and to what degree a relationship exists between two or more quantifiable variables. The object in this research is the 24 students from eight classes of students SMPN Sungaipua academic years 2019/2020 which has one class. The methods used to collect data are observation, interviews, and questionnaires. The instrument used in collecting data is a questionnaire. The technique used to analyze the data is descriptive qualitative statistics, and quantitative.

The sought correlation analysis is the coefficient of correlation, which is the number that tells the degree of relationship between the independent variable $(\mathrm{X})$ and the dependent $(\mathrm{Y})$ variable or to determine the strength or weakness of the relationship between independent and dependent variables. Multiple correlation analysis is used to determine the degree of power of the relationship between all $\mathrm{X}$ and $\mathrm{Y}$ variables. T-test tests against coefficient regression, the test is done to determine the significance of role partial between independent variables and dependent variables by assuming that other independent variables are considered constant. If there is Ho acceptance, it can be inferred that there is no significant influence, whereas when Ho is rejected, there is a significant influence. This hypothetical statistical design tests whether there is any influence between the independent variable family condition (X1), school condition (X2) regarding learning achievement (Y).

\section{RESULT AND DISCUSSION}

\section{Result}

T-test was conducted to analyze the top management support, user involvement, education, and training partially on the performance of accounting information systems. Based on the statistical calculation by using SPSS 16.0. Before conducting the t-test (hypothesis) the researcher did the F test simultaneous with results that have been processed by using the SPSS application. Based on the results of data analysis, $F=0.383$ is bigger than 0.05 . it meant that Ha was accepted and Ho was rejected, so that there was the influence between variable X1 and X2 toward Y or can be said that $0.383>0.05$. After carried out the F simultaneous, the researcher did the t-test (hypothesis) that has been calculated by using the SPSS application.

Based on the result, Ho that "there was no significant correlation between family condition toward students English achievement at VIII grade SMP N 02 Sungaipua" was rejected. Ha that "there was a significant correlation between family condition between student English achievement at VIII grade SMPN 02 Sungaipua" was accepted. Based on the result, Ho that "there was no significant correlation between school condition toward students English achievement at VIII grade SMP N 02 Sungaipua" was rejected. Ha that " there was a significant correlation between school condition between student English achievement at VIII grade SMPN 02 Sungaipua" is accepted. Besides, can be seen from the diagram below the influence between variable X1 (Family condition), variable X2 (School Condition), toward variable Y (student achievement). It can be said that there is an influence of the family condition variable (x1) on the English learning achievement of class VIII students of SMPN 02 Sungaipua (Y). There is an effect of the school condition variable (X2) on the English learning achievement of eighth-grade students of SMPN 02 Sungaipua (Y). There is a simultaneous influence of family and school conditions on learning English subjects in class VIII SMPN 02 Sungaipua.

\section{Discussion}

The relationship between family environment and school environment on English learning achievement is $5.3 \%$. This means that if the student's family environment supports and pays attention to the student's learning process, the school environment where students study in good condition can increase student achievement. Parents, mothers, and fathers play an important and very influential role in the education of their children (Cheung, SCheung \& Kwan, 2021; Dong et al., 2020). Parents' education for their children is education based on love. The main task of the family for children's education is to lay the foundation for the child's view of life (Cheung \& Yin, 2021; Kuppens \& Ceulemans, 2019). The involvement of parents towards their children in the learning process is beneficial in increasing the child's concentration. This impacts the ability of children to increase (Sary, 2018; Sorek et al., 2020). So it can be understood that parents are fathers and mothers who are responsible for children's education and all aspects of their lives since children are tiny until they are adults. After parents, learning in schools is influenced by teachers.

There is a need for teaching strategies, both in providing subject matter and growing student motivation in the learning process, because students always have differences in interests, motivation, talents, and attention to lessons (Agustuna et al., 2019; Yulianingsih et al., 2020). Professional teachers have personal, social, intellectual, moral, and spiritual responsibilities. Intellectual responsibility is realized through mastery of various sets of 
knowledge and skills needed to support their duties (Potvin et al., 2021; Yada et al., 2021). Good teachers also have adequate knowledge in the subjects they teach and continue to follow the progress (Mudiyantun, 2019; Sailer et al., 2021). Teachers must explain various information clearly and clearly, provide varied services, create and maintain momentum, use small groups effectively, encourage all students to participate, supervise, and even frequent students (Hafeez et al., 2020; Lawrence \& Tar, 2018). This will increase students' enthusiasm for learning. In addition, teachers are required to make students responsible and encourage parental participation in advancing the academic abilities of their students (Soisangwarn \& Wongwanich, 2014; Tsai et al., 2020). A good teacher must be able to demonstrate skills in planning, have the ability to organize classes, and have the ability to cope with one or more class activities at the same time. This will affect the students' English language skills which will increase.

\section{CONCLUSION}

Besides, can be seen from the diagram below the influence between variable X1 (Family condition), variable X2 (School Condition), toward variable Y (student achievement). It can be said that there is an influence of the family condition variable (x1) on the English learning achievement of class VIII students of SMPN 02 Sungaipua (Y). There is an effect of the school condition variable (X2) on the English learning achievement of eighth-grade students of SMPN 02 Sungaipua (Y). There is a simultaneous influence of family and school conditions on learning English subjects in class VIII SMPN 02 Sungaipua.

\section{REFERENCES}

Agustuna, N. E., Herlina, R., \& Faridah, D. (2019). Corrective Feedback on Pronunciation Errors: Teacher's Perception and EFL High School Students' Self-Reflection. Journal Of English Education And Teaching, 3(3). https://doi.org/10.33369/jeet.3.3.311-327

Akhmalia, N. L., Suana, W., \& Maharta, N. (2018). Efektivitas Blended Learning Berbasis LMS dengan Model Pembelajaran Inkuiri pada Materi Fluida Statis terhadap Penguasaan Konsep Siswa. JIPFRI (Jurnal Inovasi Pendidikan Fisika Dan Riset Ilmiah), 2(2), 56-64. https://doi.org/10.30599/jipfri.v2i2.299

Alam, S. K., \& Lestari, R. H. (2020). Pengembangan Kemampuan Bahasa Reseptif Anak Usia Dini dalam Memperkenalkan Bahasa Inggris melalui Flash Card. Jurnal Obsesi : Jurnal Pendidikan Anak Usia Dini, 4(1), 284. https://doi.org/10.31004/obsesi.v4i1.301

Ambussaidi, I., \& Yang, Y.-F. (2019). The Impact of Mathematics Teacher Quality on Student Achievement in Oman and Taiwan. International Journal of Education and Learning, 1(2), 50-62. https://doi.org/10.31763/ijele.v1i2.39

Arianti, Wiarta, \& Darsana. (2019). Pengaruh Model Pembelajaran Problem Posing Berbantuan Media Semi Konkret terhadap Kompetensi Pengetahuan Matematika. Jurnal Ilmiah Sekolah Dasar, 3(4). https://doi.org/10.23887/jisd.v3i4.21765

Balan, L., Yuen, T., \& Mehrtash, M. (2019). Problem-Based Learning Strategy for CAD Software Using FreeChoice and Open-Ended Group Projects. Procedia Manufacturing, 32. https://doi.org/10.1016/j.promfg.2019.02.223

Butova, Dubskikh, A., Kisel, O. V., \& Chigintseva, E. (2019). Electronic educational environment Moodle in English language training. Arab World English Journal (AWEJ), 10. https://doi.org/10.24093/awej/vol10no1.4

Chauhan, S. (2017). A meta-analysis of the impact of technology on learning effectiveness of elementary students. Computers \& Education, 105, 14-30. https://doi.org/10.1016/j.compedu.2016.11.005

Cheung, SCheung, S. K., \& Kwan, J. L. Y. (2021). Parents' perceived goals for early mathematics learning and their relations with children's motivation to learn mathematics. Early Childhood Research Quarterly, 56. https://doi.org/10.1016/j.ecresq.2021.03.003

Cheung, S. K., \& Yin, J. L. (2021). Parents' Perceived Goals for Early Mathematics Learning and Their Relations With Children's Motivation to Learn Mathematics. Early Childhood Research Quarterly, 56(3), 90-102. https://doi.org/10.1016/j.ecresq.2021.03.003

Chotitham, S., \& Wongwanich, S. (2014). The Reading Attitude Measurement for Enhancing Elementary School Students' Achievement. Procedia - Social and Behavioral Sciences, 116, 3213-3217. https://doi.org/10.1016/j.sbspro.2014.01.737

Creed, P. A., Conlon, E. G., \& Zimmer-Gembeck, M. J. (2012). Career barriers and reading ability as correlates of career aspirations and expectations of parents and their children. Journal of Vocational Behavior, 70(2). https://doi.org/10.1016/j.jvb.2006.11.001

Diana Putra, I. D. G., Darsana, I. W., \& Putra, M. (2019). Pengaruh Model Pembelajaran Berbasis Masalah Berbantuan Peta Konsep Terhadap Kompetensi Pengetahuan IPS. Jurnal Ilmiah Sekolah Dasar, 3(3), 387. 
https://doi.org/10.23887/jisd.v3i3.19479

Dong, C., Cao, S., \& Li, H. (2020). Young Children's Online Learning during COVID-19 Pandemic: Chinese Parents' Beliefs and Attitudes. Child Youth Serv Rev, 118. https://doi.org/10.1016/j.childyouth.2020.105440

Erichsen, K., \& Reynolds, J. (2020). Public school accountability, workplace culture, and teacher morale. Social Science Research, 85. https://doi.org/10.1016/j.ssresearch.2019.102347

Hafeez, M., Tahira, F., Kazmi, Q. A., \& Zahid, M. (2020). Analysis of moral reasoning of teachers and the students with respect to Kohlberg's theory of moral development. International Journal of Business Strategy and Social Sciences, $3(1)$. http://www.sciencepublishinggroup.com/journal/paperinfo?.journalid=391\&doi=10.11648/j.ijnpt.20200601 .12

Kuppens, S., \& Ceulemans, E. (2019). Parenting Styles: A Closer Look at a Well-Known Concept. Journal of Child and Family Studies, 28(1), 168-181. https://doi.org/10.1007/s10826-018-1242-x

Lawrence, J. E., \& Tar, U. A. (2018). Factors that influence teachers' adoption and integration of ICT in teaching/learning process. Educational Media International, 55(1), $79-105$. https://doi.org/10.1080/09523987.2018.1439712

Moghadam, Z. B., Narafshan, M. H., \& Tajadini, M. (2021). Development of a Critical Self in the Language Reading Classroom: An examination of Learners' L2 Self. Thinking Skills and Creativity, 3. https://doi.org/10.1016/j.tsc.2021.100944

Mudiyantun, Y. (2019). The Investigation Of Situational Leadership, And Work Motivation On Kindergarden Teacher Performance. Jurnal Kepemimpinan Pendidikan, $2(1)$. https://doi.org/10.22236/jkpuhamka.v2i1.3814

Nurlaily, V. A., Soegiyanto, H., \& Usodo, B. (2019). Elementary school teacher's obstacles in the implementation of problem-based learning model in mathematics learning. Journal on Mathematics Education, 10(2), 229238. https://doi.org/10.22342/jme.10.2.5386.229-238

Potvin, A. S., Boardman, A. G., \& Stamatis, K. (2021). Consequential change: Teachers scale project-based learning in English language arts. Teaching and Teacher Education, 107. https://doi.org/10.1016/j.tate.2021.103469

Prabaningrum, I. G. A. I., \& Putra, I. K. A. (2019). Pengaruh Model Pembelajaran Kooperatif Team Assisted Individualization Berbantuan Media Semi Konkret Terhadap Kompetensi Pengetahuan Matematika. Jurnal Ilmiah Sekolah Dasar, 3(4), 414. https://doi.org/10.23887/jisd.v3i4.21775

Purwanita, Y., Riyanto, Y., \& Suyanto, T. (2019). The Influence of Multimedia Assisted Inquiry Learning Methods on My Heroes Theme of Critical Thinking Skills and Learning Outcomes of Class IV Students ofElementary School. International Journal of Scientific and Research Publications (IJSRP), 9(7), p9169. https://doi.org/10.29322/ijsrp.9.07.2019.p9169

Retnawati, H. (2016). Proving Content Validity of Self-Regulated learning Scale (The Comparison of Aiken Index and Expanded Gregory Index). Research and Evaluation in Education, 2(2), 155-164. https://doi.org/10.21831/reid.v2i2.11029

Rosalina, A., Widyasari, Y., Ismi, M., \& Hapsari. (2010). Peranan Orangtua Dalam Dongeng Sebelum Tidur Untuk Optimalisasi Kemampuan Berkomunikasi Anak Usia Dini. Psycho Idea, 8(2). https://doi.org/10.30595/psychoidea.v8i2.236

Rubini, B., Permanasari, A., \& Yuningsih, W. (2018). Learning Multimedia Based on Science Literacy on the Lightning Theme. Jurnal Penelitian Dan Pembelajaran IPA, 4(2), 89-104. https://doi.org/10.30870/jppi.v4i2.3926

Sailer, M., Stadler, M., Schultz-Pernice, F., Franke, U., \& Schöffmann, C. (2021). Technology-related teaching skills and attitudes: Validation of a scenario-based self-assessment instrument for teachers. Computers in Human Behavior, 115. https://doi.org/10.1016/j.chb.2020.106625

Sary, Y. N. E. (2018). Relationship of Parenting with Child Interpersonal Intelligence in Wonokerto Village, Lumajang Regency. Jurnal Obsesi: Jurnal Pendidikan Anak Usia Dini, 2(2). https://doi.org/10.31004/obsesi.v2i2.93

Schildkamp, K., Kleij, van der, Heitink, Kippers, W. B., \& Veldkamp, B. P. (2020). Formative assessment: A systematic review of critical teacher prerequisites for classroom practice. International Journal of Educational Research. https://doi.org/10.1016/j.ijer.2020.101602

Sert, N., \& Boynueğri, E. (2017). Digital technology use by the students and english teachers and self-directed language learning. World Journal on Educational Technology: Current Issues, 9(1), 24. https://doi.org/10.18844/wjet.v9i1.993

Slade, M. ., Burnham, T. ., Catalana, S. ., \& Waters, T. (2019). The impact of reflective practice on teacher candidates' learning. International Journal for the Scholarship of Teaching and Learning, 13(02), 1-8. 
https://doi.org/10.20429/ijsotl.2019.130215

Soisangwarn, A., \& Wongwanich, S. (2014). Promoting the Reflective Teacher through Peer Coaching to Improve Teaching Skills. Procedia - Social and Behavioral Sciences, 116. https://doi.org/10.1016/j.sbspro.2014.01.601

Sorek, Y., Simon, B. Ben, \& Ektelat, F. N. (2020). Motivation Matters: Parents' Path to Adoption as Related to Their Perceptions of Open Adoption. Children and Youth Services Review, 118(11), 105430. https://doi.org/10.1016/j.childyouth.2020.105430

Tempelaar Chan, S. L., Lin, C. C., Chau, P. H., Takemura, N., \& Fung, J. T. C. (2021). Evaluating online learning engagement of nursing students. Nurse Education, 104. https://doi.org/10.1016/j.nedt.2021.104985

Timmermans, A. C., Werf, M. P. C. G. van der, \& Rubie-Davies, C. M. (2019). The interpersonal character of teacher expectations: The perceived teacher-student relationship as an antecedent of teachers' track recommendations. Journal of School Psychology, 73. https://doi.org/10.1016/j.jsp.2019.02.004

Trentman, E. (2017). Oral fluency, sociolinguistic competence, and language contact: Arabic learners studying abroad in Egypt. System, 69. https://doi.org/10.1016/j.system.2017.08.007

Tsai, M.-N., Liao, Y.-F., Chang, Y.-L., \& Chen, H.-C. (2020). A brainstorming flipped classroom approach for improving students' learning performance, motivation, teacher-student interaction and creativity in a civics education class. Thinking Skills and Creativity, 38. https://doi.org/10.1016/j.tsc.2020.100747

Verner, I., Massarwe, K., \& Bshouty, D. (2013). Constructs of engagement emerging in an ethnomathematicallybased teacher education course. The Journal of Mathematical Behavior, 32(3). https://doi.org/10.1016/j.jmathb.2013.06.002

Wau, M. P. (2017). Pengaruh Model Problem Based Learning Terhadap Hasil Belajar Ips Pada Siswa Kelas Iv Sdi Bajawa Kecamatan Bajawa Kabupaten Ngada. Journal of Education Technology, 1(4), 239. https://doi.org/10.23887/jet.v1i4.12860

Wongwanich, S., Sakolrak, S., \& Piromsombat, C. (2014). Needs for Thai Teachers to Become a Reflective Teacher: Mixed Methods Needs Assessment Research. Procedia - Social and Behavioral Sciences, 116. https://doi.org/10.1016/j.sbspro.2014.01.450

Yada, A., Björn, P. M., Savolainen, P., Kyttälä, M., \& Aro, M. (2021). Pre-service teachers' self-efficacy in implementing inclusive practices and resilience in Finland. Teaching and Teacher Education, 105. https://doi.org/10.1016/j.tate.2021.103398

Yulianingsih, W., Suhanadji, S., Nugroho, R., \& Mustakim, M. (2020). Keterlibatan Orangtua dalam Pendampingan Belajar Anak selama Masa Pandemi Covid-19. Jurnal Obsesi : Jurnal Pendidikan Anak Usia Dini, 5(2), 1138-1150. https://doi.org/10.31004/obsesi.v5i2.740

Yusuf, K., \& Mabagits, S. (2020). Does Activeness in Organization Improve English Speaking Skill? University Students' Perspective. Leksika Jurnal Bahasa, Sastra Dan Pengajarannya, 14(2). https://doi.org/10.31838/jcr.07.12.41 